\title{
THE VIENNA BRUEGEL PROJECT: EXHIBITION, CATALOGUE AND SYMPOSIUM
}

\author{
Bruegel: The Hand of the Master = Die Hand des Meisters \\ By Elke Oberthaler, Sabine Pénot, Manfred Sellink, and Ron Spronk, with Alice Hoppe-Harnoncourt \\ Edited by Alice Hoppe-Harnoncourt, Elke Oberthaler, and Sabine Pénot \\ Exhibition catalogue (Kunsthistorisches Museum, Vienna, 2018-2019), Vienna, 2018. 303 pages \\ E-book: Bruegel: The Hand of the Master = Die Hand des Meisters \\ By Elke Oberthaler, Sabine Pénot, Manfred Sellink, and Ron Spronk, with Alice Hoppe-Harnoncourt \\ Edited by Alice Hoppe-Harnoncourt, Elke Oberthaler, and Sabine Pénot \\ Exhibition catalogue (Kunsthistorisches Museum, Vienna, 2018-2019), Vienna, 2018 \\ To access the e-book, click on the following link and enter the access code given in the printed version: \\ www.khm.at/bruegel_ebook
}

Symposium: The Hand of the Master. Materials and Technique of Pieter Bruegel the Elder. 6-8 December 2018. Kunsthistorisches Museum, Vienna, Bassano Hall

Charles de Tolnay (Károly Tolnay), a relatively early - if not the first - researcher of Bruegel's art, stated the following about his scholarly endeavours: "When I was young it was my ambition to survey the entire history of European art and the essence of its development. I selected the masters that are key figures in this respect; it is only through them that the development can be understood in full. This is what I call my pantheon." In Tolnay's well-defined category, the Netherlandish art of the fifteenth-sixteenth centuries

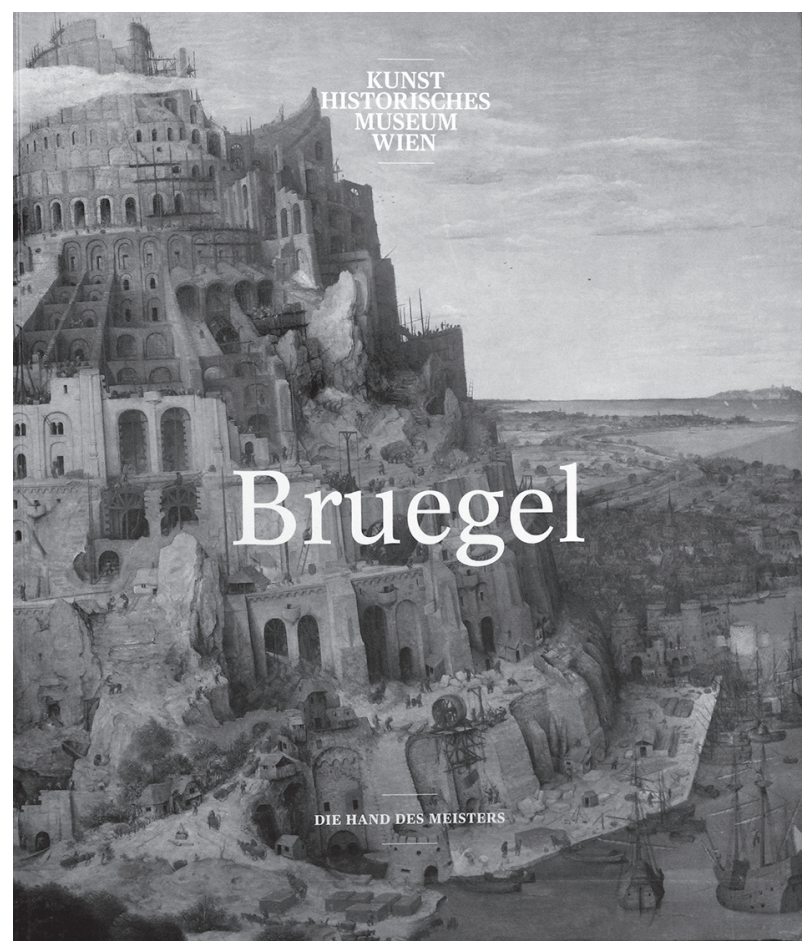

was represented primarily by Jan van Eyck, Robert Campin, Hieronymus Bosch, and Pieter Bruegel the Elder. ${ }^{2}$ In the hundred or so years since the publication of Tolnay's work and the first twentieth-century approaches (Max J. Friedländer, Ludwig von Baldass, Max Dvořak), writings by art historians on Bruegel have offered an almost unmatched diversity of views and issues. Yet the aim has remained the same: to get ever closer to the genius of the Flemish master and his role as a "key figure" in art. Signifying novel directions of research, a new juncture in this process was the Bruegel exhibition held in Vienna to mark the 450th anniversary of the master's death. The exhibition was accompanied by the publication of a voluminous exhibition catalogue, an e-book and a website (insidebruegel.net) and by the holding of a three-day international symposium.

Both for the museum and in terms of research opportunities, the project in Vienna was a veritable success, as reflected in the visitor numbers and the research results. Media outlets caught the public's attention by using punchy slogans such as "only in Vienna" or "once in our lifetime" to describe the exhibition. In this instance, however, such advertising statements were grounded in fact. The leading role of Vienna stems from the fact that the subject matter and departure point of the research work that was conducted for several years prior to the exhibition, were the twelve paintings - twelve main works - held by the Kunsthistorisches Museum, most of which were brought, as part of the Habsburg collections, to Vienna in the seventeenth century and were subsequently 
incorporated into the collection of the Kunsthistorisches Museum, with further pieces being added later on. The dozen works make up a quarter of the painting oeuvre that has survived from the last decade or so of Bruegel's life. They include essential works that can be used to encapsulate the chronological and thematic development of the Flemish master's painting oeuvre. We know of dated paintings by Bruegel from as early as 1557 , but there are no surviving paintings from his time as a pupil in the workshop of Pieter Coecke van Aelst (roughly from 1545-1550) or from his journey to Italy in 1552-1554. The earliest of the paintings held in Vienna is The Battle between Carnival and Lent from 1559, and the timeline ends with several late works from 1567 and 1568: The Conversion of Paul, Peasant Wedding, Peasant Dance, and The Birdnester. Some of these paintings are 'encyclopaedic' works with multiple figures, while others evoke the detailed scenes of miniature paintings. Still others are compositions with more monumental figural-spatial arrangements. The themes of the various works also encapsulate Bruegel's oeuvre: the exhibition included religious pieces with social critical overtones, emblematic landscapes, crowd scenes (Wimmelbilder) and peasant paintings. The latter illustrates the humanism, refined meaning and humour that characterise the master's intellectuality, offering insights into the intellectual history of the period.

The Bruegel Project in Vienna forms part of a major interdisciplinary international research effort that began almost two decades ago. With the support of the Getty Conservation Institute, the Getty Foundation, and the Getty Museum the Panel Paintings Initiative was established in the late 1990s. The Initiative aimed to examine and analyse the panel paintings, to disseminate knowledge of conservation and restoration methods, to train experts, and to support relevant research work. In 2012, they signed an agreement with the Kunshistorisches Museum on a comprehensive technical survey of the Bruegel panel paintings held by the museum and on funding for their possible conservation or restoration. ${ }^{3}$ The team conducting the research and restoration work was in operation for around six years and included leading experts in the field: Sabine Pénot (curator, KHM, Vienna), Ron Spronk (professor, Queen's University, Kingston), Manfred Sellink (director and lead curator, Koninklijk Museum voor Schone Kunsten, Antwrep), Elke Oberthaler (restorer, KHM, Vienna), and Alice Hoppe-Harnoncourt (curator, KHM, Vienna). The technical analysis was undertaken by, among others,
Getty's experts as well as the panel painting conservators George Bisacca (Metropolitan Museum, New York), José de La Fuente (Museo Nacional del Prado, Madrid), Ray Marchand (Ebury Street Studio, London), and Pascale Fraiture (IRPA/KIK, Brussels). In the course of the project many external conservators received opportunities for workshop consultations and the exchange of experiences.

The exhibition held in Vienna in 2018-2019 constituted a summary of the research results. An exhibition catalogue was published in English and German, the texts of which were prepared by the curators. Those who are interested can access the section of the catalogue containing the studies in the form of an e-book. This document, which is available in pdf format (in high or low resolution), is also in German and English and contains the entire catalogue, supplemented by the studies. The printed catalogue includes a valuable introduction as well as detailed information on all the exhibited works. A detailed and thorough basic data section introduces the various items, while the analytical texts are accompanied by high quality printed reproductions and bibliographical notes. The various works are presented in chronological order, enabling readers to follow the development of Bruegel's art and, more or less, the thematic groups of the oeuvre. The contents of the catalogue, the structure and focus of the studies adhere to the ideas formulated in the curators' introduction. According to the curators, the aim of the project in Vienna was to offer an unparalleled introduction to the master's oeuvre and to present new findings on the various works while reconsidering previous statements and conclusions. A further aim was to explore and demonstrate the creative methods of the master, doing so based primarily on the results of the technical analysis. The Internet publication supplements the catalogue with five studies, also authored by the curators. Three of these studies summarise the technical findings, each with a different focus point (Sellink, Spronk, Oberthaler, 295-315; 355-367; 369-427). The high-resolution standard photos and the infrared and X-ray images made during the technical examinations are accessible on the project website - reflecting the general trend of recent years (see, for instance, Cranach Digital Archive or Closer to Van Eyck). This significantly broadens the possibilities open to researchers. The research programme, which lasted for several years, also provided opportunities for studies on the reception and research history of works by the Flemish master as well as a detailed investigation of the history of the paintings in Vienna. In my 


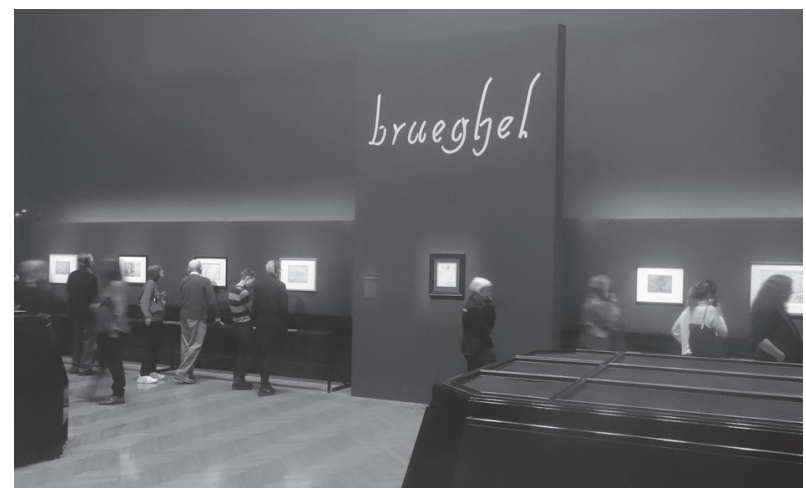

view, this constitutes a major contribution to research on the artist's oeuvre, one that promises many fascinating discoveries. Two of the studies address these issues and questions (Pénot, Hoppe-Harnoncourt, 317-329; 331-353).

Most of the nineteen lectures given at the symposium also addressed these issues, although there were no strict thematic parameters. Many other interesting topics arose, from an analysis of Bruegel's time in Antwerp (Jan Van der Stock: Pieter Bruegel. Draughtsman and Painter in Antwerp. Exploring His Origins and Friends) to a possible explanation of the common use of the pitcher motif in the paintings (Claudia Goldstein: Pieter Bruegel and Realia. Context and Reception of His Paintings). Speakers at the symposium included renowned researchers on the period as well as younger art historians. Those in attendance heard accounts of the research carried out by Joris van Grieken (Bibliothèque royale de Belgique, Brussels), Lieve Watteeuw (Illuminare - University of Leuven), Till-Holger Borchert (Musea Brugge), Hans J. van Miegroet (Duke University, Durham NC), Christina Currie (KIK/ IRPA), Dominique Allart (Université of Liège), Ingrid Hopfner, Georg Prast (KHM, Vienna), Tine Luck Meganck (Musée royaux des Beaux-Arts de Belgique, Brussels). In the following, I seek to offer an overview of the project in Vienna by means of a cross-section of the exhibition, catalogue and symposium. I thus describe the exhibition, while also referring to several aspects of the catalogue and the symposium.

The exhibition's curators succeeded in rendering the highly significant holdings in Vienna into a comprehensive monographic review. They did so, despite the fragility and great value of the master's surviving paintings. There can be no doubt that a similar exhibition of Bruegel's work will not be held for some decades to come. The Vienna exhibition comprised nearly thirty paintings - three-quarters of the known oeuvre - and around half of the surviving drawings

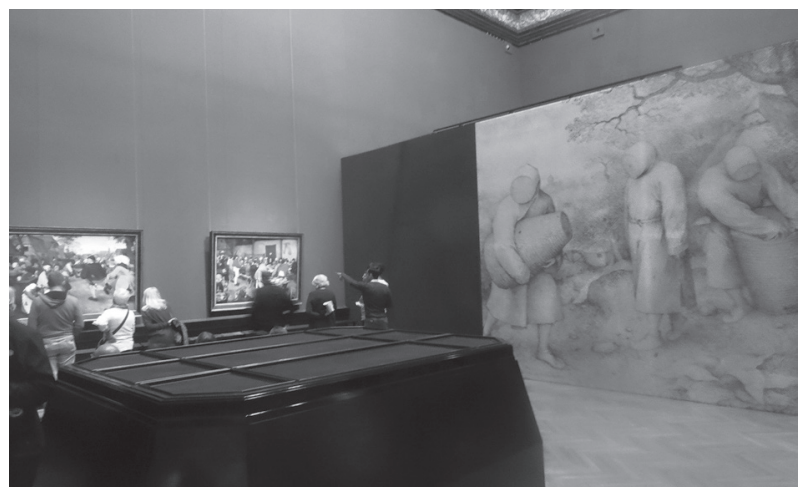

and prints made after drawings. The paintings on loan were the highlights of different collections. Moreover, the wooden panels, most of which are thinned, are prone to damage. This greatly increased the risks of delivery and installation. According to current borrowing guidelines, an exhibition concept with scientific aims is required in order to transport the wooden panels (which are hundreds of years old), the jealously guarded freehand drawings, and the few surviving copies of the graphic works. It must be an occasion and context that will significantly contribute to the knowledge, value and status of the works that brings them together. The Vienna exhibition clearly offered such a milieu for the exhibited works, and so it became possible for Bruegel's oeuvre to be viewed at one venue and as a unity. A brief glance at the borrowed masterpieces reveals the presence in the exhibition of View of the Bay of Naples (Galleria Doria Pamphilij, Rome, cat. 54), which has been regarded as the artist's own work since its restoration in 2015, Two Monkeys (Gemäldegalerie, Staatliche Museen zu Berlin, cat. 59), The Triumph of Death (Prado Museum, Madrid, cat. 60), the Rotterdam version of The Tower of Babel (Museum Boijmans van Beuningen, Rotterdam, cat. 64), which was displayed for the first time with the Vienna version, The Adoration of the Magi (National Gallery, London, cat. 66), which reveals the strong influence of Bosch, and the delicate grisaille paintings: The Death of the Virgin (Upton House, Bearsted Collection, Banbury, cat. 68) and Three Soldiers (The Frick Collection, New York, cat. 86). Among the graphic works, it is worth mentioning Bruegel's early drawings made during his travels to and in Italy and the later series of Large Landscapes as well as The Seven Virtues and The Seven Capital Sins (cat. 34-45; 23-30). Several pieces that have an important place in the oeuvre were absent from the exhibition, however. For instance, the exhibition did not include the painting The Harvesters held by the Metropolitan Museum of Art, New York, which would 


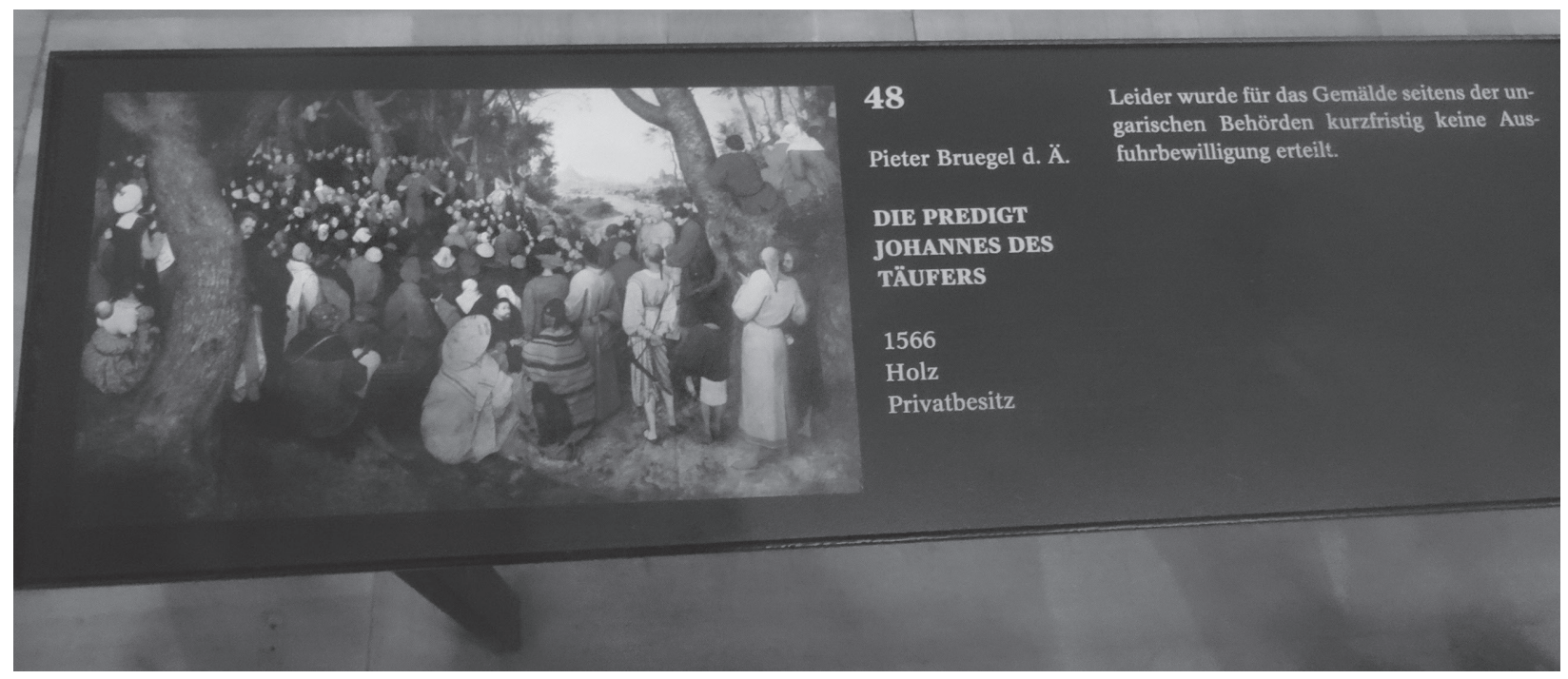

have completed the Seasons cycle, which doubtless originally included six pictures but today comprises just five works. Among the drawings linked with the journey to Italy, the following were not included in the exhibition: River Valley in a Hilly Landscape (Musée du Louvre, Paris), which belongs to the earliest group from 1552, and Monastery in a Valley (Kupferstichkabinett, Staatliche Museen zu Berlin). It would have been instructive, in terms of artistic development, to see one of Bruegel's earliest surviving paintings, Landscape with the Parable of the Sower (1557, Timken Art Gallery, San Diego), or, among the later works, the iconic Lazy-Luscious Land (1567, Bayerische Staatsgemäldesammlungen, Alte Pinakothek, Munich). From a Hungarian vantage point, the most glaring omission was that of The Sermon of Saint John the Baptist, a work that has been returned to the Batthyány family. The Hungarian Prime Minister's Office (Heritage Preservation Authority) declined to give permission for the protected painting, which is on deposit at the Museum of Fine Arts in Budapest, to be loaned to the Vienna museum. The backdrop to this decision could be a claim to the painting made by the Güssing Foundation (Burgenland, Austria), which manages the family's chateau in Güssing and all related assets. Although the catalogue mentions this work, its absence from the exhibition was nevertheless an enormous loss, as we could not see it in the company of the other Bruegel works. Sadly, there is little chance of a similar opportunity arising again soon. Bruegel's paintings on canvas (i.e. the Tüchlein paintings) were also absent from the exhibition; they were not borrowed on account of their fragility. Executed without a preparatory layer, these tempera paintings have very delicate colours and shadows and constitute special works. In Bruegel's period and in earlier times, many hundreds of these works were made in the workshops of the Netherlandish painters. Their absence from the exhibition is compensated for both by the catalogue, which includes an entry on The Adoration of the Magi (Musée royaux des BeauxArts, 60-63), treating it as Bruegel's own work even though the literature is divided on the issue, and by the lectures given at the symposium. Angela Cerasuolo presented a full technical examination of the Naples version of The Parable of the Blind and The Misanthrope and she also compared those paintings with the surviving copies (Tüchlein from the Museo di Capodimonte, Naples). As far as The Misanthrope is concerned, she convincingly drew a connection between the characteristics and features of the underdrawing and the famous work by Bruegel known as The Painter and the Connoisseur (Albertina, Vienna). Hans J. van Miegroet (Traces of Lost Pieter Bruegel Paintings Revealed Through Derivative Paintings, Phantom Copies, and Dealer Practices), in connection with the copies made after Bruegel and the practices of art dealers in the period, gave a detailed account of the quantity and significance of the works on canvas, as well as the relationship between contemporary originals and copies. Bruegel's Tüchlein works constituted the last examples of this technique in the Southern Netherlands; from the latter third of the sixteenth century, the technique was no longer used. The works made using this technique, which had been around for several hundred years, occupy a particularly interesting place in Bruegel's oeuvre. Until recently they had been rather neglected.

Leaving aside a few copies made after Bruegel and some portrayals relating to collection history, the 


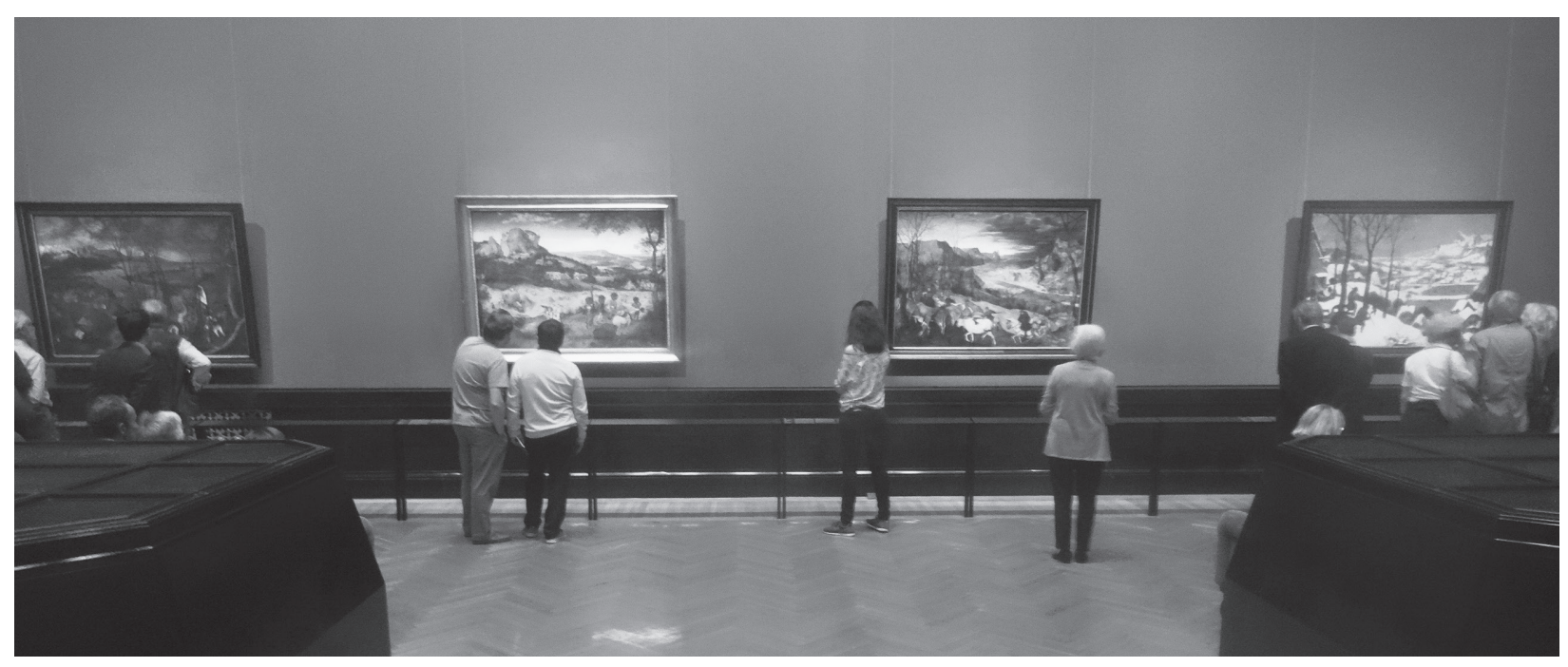

exhibition in Vienna revealed to viewers the art of the Flemish master in all its sharp-edged purity. The paintings, drawings and engravings, which numbered in total almost ninety, where possible were displayed into thematic groups and in chronological order. The art of Bruegel ran from the early landscapes to the late peasant paintings, the latter having often "marked" the entire oeuvre. In the first halls of the exhibition, viewers gained insights into Bruegel's draughtsmanship, from the work dated to 1552, the Path through a Village (cat. 1), which was discovered relatively later, to the Large Landscapes, the engravings made after Bruegel's drawings, and the famous View of the Ripa Grande (cat. 18) in Rome. Whereas in respect of the Large Landscapes, only the engravings made after the drawings were included in the exhibition, among the allegories reminiscent of Bosch both the original drawing and the engraving of the Temptation of Saint Anthony (1556) were on view, permitting a comparison of the two techniques (cat. 19-20). As far as The Seven Capital Sins and The Seven Virtues series (cat. 23-30; 43-45) are concerned, in some cases the original Bruegel drawing was displayed together with the engraving after it by Pieter van Heyden or by Philipps Galle, while in other cases only the engravings were exhibited. Bruegel's paintings were shown, in the first rooms of the exhibition, together with the drawings, selected according to themes. In this way, the works in the Seasons cycle could be viewed in the context of the landscape drawings. This arrangement was a superb opportunity to compare or contrast the compositions and motifs of the various drawings and paintings. A watchful eye could easily spot the correspondences and similarities noted by Sellink in the e-book. Placing these works in the same space as the so-called Wim-

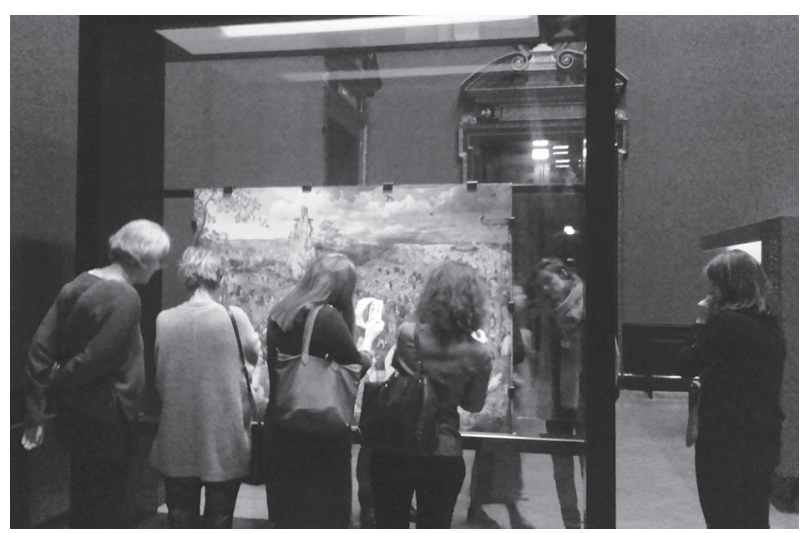

melbilder underlined the diversity of Bruegel's compositional techniques. The religious paintings constituted another thematic group, as did also the The Seven Capital Sins and The Seven Virtues series. One of the surprises of the exhibition was the installation of the Christ Carrying the Cross (cat. 67) with the original panel width and the reverse: it was exhibited without a frame and in such a position that the reverse was visible. Visitors to the exhibition were thus able to acquaint themselves with the otherwise hidden features of the panel paintings of the period. Such features are, for instance, the unpainted border that runs around the painted surface, the finishing of the reverse of the panel, and the inscriptions and labels fixed to the reverse. In a separate room, visitors to the exhibition could view the works executed with miniaturelike precision, including the two versions of The Tower of Babel (cat. 63 and 64), The Suicide of Saul (cat. 57), and View of the Bay of Naples. The painting technique of the Flemish master and the preparatory works of his paintings were presented in the cabinets: visitors could learn about the preparatory stages of a painting and 
the master's creative process from concise descriptions of the technical features and highly illustrative photographs (of the technical examinations, woodworking, underdrawing, and Bruegel's special painting surfaces). The same aim was served by the photographs documenting the restoration of The Suicide of Saul, which was accompanied by a short explanatory text and a reconstruction work. This practice has become increasingly popular in recent years. A faithful copy of the Berlin version of Two Monkeys was made especially for the exhibition, and the processes of its execution were exhibited together with both the completed copy and the original painting (there can be no doubt that while in a technological sense the copy faithfully adheres to the original, the essence of Bruegel's original work has been lost, as is usually the case with copies). The work, which assumed and required an exact knowledge of the creation of the original painting, was described at the symposium by Babette Hartwieg and Bertram Lorenz (Technological Research of the Panel Two Monkeys and the Making of a Reconstruction). The curators devoted the final room to Bruegel's late works, including the peasant paintings and The Birdnester (cat. 81-84). As regards the arrangement in full, it was noticeable that the description and illustration of technical issues was usually done in separation from the original works. Although, by making this distinction, the curators ensured that Bruegel's works were placed in a contextual relationship and could be studied and compared by viewers without difficulty, the technical features were nevertheless assigned a somewhat secondary role. This lack of an integral approach was, however, compensated for in full by the catalogue and by the symposium proceedings.

Whilst Bruegel does not require further elevation or promotion, a monographic exhibition was clearly an opportunity to underline the visual spectacle and quality of his work. Visitors to the exhibition in Vienna could partake in a special aesthetic experience: this is the intensity and delicate rousing of the genius of Bruegel and the tension arising from the baffling nature of the masterpieces in a Kantian sense, elicited in the first place by the peculiarly uniform quality of the works. It sometimes seems as though Bruegel's hand never erred. His excellent compositional skills and his knowledge of draughtsmanship are made perfectly manifest, not only in his drawings, but also in his paintings. And it is perhaps this artistic feature, which is given emphasis by means of colour and light, that ensures the exceptional artistic quality of his paintings with their miniaturelike precision and their monumentality. The artistic clarity and vocabularic diversity are grounded in the fact that although Bruegel took much inspiration from the art of earlier generations and his contemporaries (for a long time, a topic in research on Bruegel has been the influence of fifteenth-century Flemish miniature painting, Bosch or even the works of the Italian Renaissance and of contemporaries, which the articles in the catalogue also cover in almost all cases) and then reinterpreted such influences in accordance with his own tonality, some of the details and features of his works nevertheless seem to be very modern. On seeing the landscape background of Hunters in the Snow (cat. 75) or the well-defined figures of the peasant scenes, the viewer may call to mind the study by the prematurely deceased Leó Popper, who boldly proposed a link between the art of the Flemish painter and that of Cézanne. ${ }^{4}$ In the quality of Bruegel's work as experienced at the exhibition, there is only one piece where a degree of confusion may be felt, namely in the recently discovered painting entitled The Drunk Cast into the Pigsty (cat. 22.). While researchers have been reluctant to accept its attribution to Bruegel (an attribution that was first proposed in 2000), ${ }^{5}$ in the Vienna exhibition catalogue Manfred Sellink offers persuasive reasons for doing so, notwithstanding his earlier uncertainty. In line with the earlier proposal, Sellink regards the work as one of the master's early paintings. Yet the somewhat impaired artistic quality of the tondo becomes readily apparent in the company of other works. This is most certainly due to the poorer quality of the details, which results from the repainting and the inexperience of the painter, to which reference was made when the attribution was first made. Despite all this, however, one should perhaps give attention to the clumsiness of the movement of the figure with his arms outstretched or to the unjustifiably schematic form of the hands; in vain do we search for the excellent draughtsmanship that otherwise defines Bruegel's paintings. Here, it should be mentioned that, save for the aforementioned View of the Bay of Naples, the exhibition included no works whose attribution is disputed in the literature. ${ }^{6}$ While this served to guarantee the quality of the exhibited works, it would have been interesting, perhaps, to compare and contrast one or two other pieces with the artist's own works.

But let us now return to the significance of the project for art history and to its results and findings, which are to be found in the technical information offered 
as well as in the details relating to the master's reception and especially to his works in the Vienna collection. The exhibition began with these two aspects in mind: indeed, at the start of the exhibition, visitors were met by the greatly enlarged details of one or another of Bruegel's paintings. This encouraged viewers to seek out the otherwise barely discernible motifs and to look out for the painting techniques and virtuoso skills of the master. At the beginning of the exhibition, an installation with illustrations offered succinct information about the contemporary and subsequent reception and financial value of Bruegel's art. This very interesting issue, which nevertheless seemed somewhat out of place at the exhibition as it was outside the scope of the main theme, was treated in the studies of two curators, Pénot and Hoppe-Harnoncourt, and in their lectures at the symposium. Pénot focused upon early scholarship on Bruegel, which took place in Belgium and in Vienna (lecture: Bruegel Scholarship in Vienna), while HoppeHarnoncourt outlined the history of Bruegel's paintings in Vienna (lecture: Bruegel's Paintings in the Early Years of the Kunsthistorisches Museum). Pénot had been motivated to study and analyse early scholarship on Bruegel's art (and its rediscovery) by the lack of any consensus among current researchers on Bruegel and on these issues. By means of a careful and judicious selection, Pénot's essay and lecture offered guidance in terms of the main directions of research, pointing to the diversity of the nineteenth-century and twentiethcentury approaches - from the stylistic considerations that narrowed the oeuvre, to the iconographic analyses that were so popular among researchers following in the footsteps of Panofsky, to anthropological research and the studies that sought to define Bruegel's intellectual milieu, to the concept for the Bruegel project in Vienna in 2018-2019. This valuable albeit necessarily condensed study on the reception and research history of Bruegel's work - it would have been good to hear more about the nineteenth-century (re)discovery of fifteenth-sixteenth-century art, especially about the categorisation of paintings as "early works" - is of key importance to gaining an overview of his oeuvre. Knowledge of the reception of the artworks in later periods contributes to a more nuanced overall view, given that in the case of an artist of the quality of Bruegel, who has been analysed and debated from so many different vantage points, it is no easy task to peel away the various interpretations that have become adhered to various subject matters in the course of earlier appraisements.
This reception history is rendered even more nuanced by gaining knowledge about the fate of the works in Vienna. Hoppe-Harnoncourt's paper and lecture offer an extraordinarily detailed account of the history of the works in Vienna, from the sixteenth until the mid-twentieth century. A strength of her approach was that she not only summarises the various research findings and data on the topic but also provides much new information. In doing so, she presents the various periods in the history of the Vienna works in the context of the reception of Bruegel's art. The most interesting aspect is the fate of the pictures in the eighteenth and nineteenth centuries. In a very tangible way she highlights the preferences of the various eras, from the neglect of the Baroque era, to the encyclopaedic and didactic tendencies in the late eighteenth century, to the historical interest in, and rediscovery of, the art of the fifteenth and sixteenth centuries, which accompanied the Romantic movement of the nineteenth century. These changes of approach are best demonstrated by Hoppe-Harnoncourt in the history of the Seasons cycle. Finally, reference should be made to a surprising finding that relates to collection history in Hungary: although the matter has been debated previously, ${ }^{7}$ the Hungarian public is still perhaps rather unacquainted with the story of the Adoration of the Magi. The painting was brought to Buda Castle during the reign of Joseph II but then returned to Vienna in 1850. Subsequently, however, it was mysteriously lost. In 1893 it was offered for sale to the director of what later became the Picture Gallery (Vienna), but the deal fell through. Finally, in 1920, the work was acquired by the National Gallery in London. It seems highly likely that between 1772 and 1781 the works Harvesters and The Return of the Herd were also held at the Royal Palace in Buda (cat. 74), before they were returned to the Picture Gallery in Vienna (352, note 81).

The true milestone, however, concerns the findings of the technical examinations conducted in the course of the project. Prior to the project in Vienna, technical observations were conducted in relation to sixteen works by Bruegel. In connection with an exhibition or an acquisition, examinations were conducted on The Feast of Saint Martin (Museo Nacional del Prado, Madrid), on the Dulle Gret (Mad Meg) picture and on Bruegel's grisaille paintings. ${ }^{8}$ The three-volume Brueg(h)el Phenomenon, published in 2012, describes the (copying) techniques and working methods of Pieter Bruegel the Elder and Jan Breugel the Elder by focusing on, among others, the painting The Sermon of Saint John the Baptist. ${ }^{9}$ On the present occasion, an 
analysis of the twelve panels in Vienna, which span Bruegel's painting oeuvre, permitted the systematisation of the investigations and the summation of the results.

In accordance with twenty-first-century standards, the Vienna paintings were examined using noninvasive methods. Such methods include observations with the naked eye and the use of scientific instruments. The examinations related to both the painted surface and the panel structure and comprised highresolution photography, X-ray and infrared imaging, ultraviolet photography, and dendrochronological analysis. Sellink, Oberthaler and Spronk summarised the findings of the examinations and placed them in an art historical context in their three studies contained in the e-book. Oberthaler provides highly detailed and comprehensive findings on the various elements (wood panel, preparatory layers, underdrawing, paint layers, and pigments), thereby providing a very rich "resource" to art historians. In her essay, she also presents findings and data concerning the history (physical condition) of prior restorations of the pictures. Such data facilitate a proper understanding of the fate of the works and their current condition and thus may assist in determining the stages of any modern restoration work. For example, based on the surviving documents, the various aspects of the history of the gallery, and the technical observations, we can now be certain that the following works have been cut: The Tower of Babel, The Conversion of Paul, The Suicide of Saul, and The Birdnester. The paper also presents the works in their "complete" digitised forms, providing further nuance to appraisals of Bruegel's compositional skills (411, 67a-d. image).

Based on the information provided in the paper, we might think that the examination of the works in Vienna did not give rise to any particular surprises; almost all the details - the use of Baltic oak, the joining of the planks, the chalk-glue ground, the tone of the imprimatura, the use of underdrawing, the selection of pigments - accord with the practices of sixteenthcentury Netherlandish art. Moreover, the findings of the dendrochronological analysis were in line with the dating results, offering an opportunity for the planks to be grouped by trunk.

Notwithstanding the above, the examinations were hugely significant in relation to the various works, raising many new questions concerning the creative process. Among the various stages of that process, the most important - as far as Bruegel's art is concerned - is possibly the underdrawing, as there are no surviv- ing preparatory drawings that were definitely used by Bruegel when creating his pictures, and - as earlier research has shown - Pieter Bruegel the Younger may have used full-size sketches and cartoons for his compositions after his father's paintings that were made after, or perhaps for, the originals. ${ }^{10}$ Among the various pictures or even within individual works, there are significant differences in the type of Bruegel's underdrawings (freehand drawings with many changes; outline sketches; detailed underdrawings). The exhibition presents a characteristic example of this in the form of enlargements of the underdrawing for The Tower of Babel. Spronk's essay draws attention, among other things, to a special feature of Bruegel's creative method in respect of a group of the underdrawings. Bruegel's underdrawing of certain figures and details in some of the works (e.g. some of the figures in Peasant Dance) leads one to conclude that he may have used his own cartoon when formulating a composition. The significance of this observation for art history is that this method was usually used in Netherlandish painting in the course of copying. (It is, however, worth noting that we find a great number of techniques indicating a mechanical process on the own works of other Netherlandish masters, such as Isenbrant, Barend van Orley, Joos van Cleve, albeit in their works too, the use of a cartoon is explained by copying or repeating.) In Bruegel's case, we have no knowledge of a composition being produced in several copies. Consideration should clearly be given to Spronk's idea that the use of cartoons stems from Bruegel's time at Van Aelst's workshop. Van Aelst was a multifaceted and soughtafter artist who also made stained-glass windows and tapestry designs. According to Spronk, it was from him that Bruegel learnt how to make full-size cartoons. Spronk also argues that Bruegel may have collaborated on the Conquest of Tunis tapestry series, for which his master has received a commission. The same conclusion is made by Sellink in his paper (in the e-book) analysing Bruegel's compositional schemes. He raised this possibility based on the similarity of compositions seen in Bruegel's pictures and in tapestries attributed to Van Aelst. Both approaches are fascinating, if for no other reason than that, in view of their very different figures and styles, the relationship between the art of Bruegel and that of Van Aelst has never been in the spotlight of researchers. These issues and their exploration may be one of the most interesting fields of research on Bruegel in the future.

In addition to these studies, the art historical analyses in the printed catalogue also made use of the find- 
ings of the technical examinations. To mention merely a few examples: in view of the clear and disciplined drawings for The Battle between Carnival and Lent and Children's Games, it had been thought that a cartoon was used. The X-ray imaging revealed however, several details hidden by subsequent overpainting, and these details reflect Bruegel's more drastic ideas about, among other things, the transience of life. The Suicide of Saul, a small-sized work, was restored as part of the project, with its restoration being preceded by technical analysis. All this tended to confirm the oft-cited idea that Bruegel mastered the miniature painting techniques from Mayken Verhulst, Van Aelst's wife. Verhulst, who later became Bruegel's mother-in-law, was a renowned miniature painter in the period. Two works, the Dulle Griet (cat. 61, Museum Mayer van den Berg, Antwerp) and The Triumph of Death (cat. 60, Museo Nacional Prado) have been restored for the exhibition in Vienna and thus presented in their original quality. After the restoration, the date visible on Dulle Griet was changed to 1563 (from 1561). The change in the dating marks a rejection of the earlier hypothesis that the two pictures had belonged, together with the Brussels panel The Fall of the Rebel Angels (1562, Musée royaux des Beaux-Arts), to the same cycle. I note that Dulle Griet and The Triumph of Death were placed on two sides of a doorway at the exhibition. This made it difficult for the viewer to reflect on the affinity of the two works. In the case of Christ Carrying the Cross the examinations resulted in new findings relating to one of the most researched details, namely the stylistically rather Gothic group of the Marys and Saint John, as well as to the function of the picture. Not only is it different in style, but also the selection of pigments and the type of underdrawing of this detail differ from those used in the painting. The authors of the entry (Pénot / Oberthaler) identified the pictorial sources of the scene (Raffaelo, or Barend van Orley and Pieter Coecke van Alest) and confirmed the painting's Andachtsbild function, which had been proposed by earlier researchers. Bruegel's intention of establishing contact with the viewer is exemplified by the figure of the horse standing in front of Christ: the head posture was repeatedly corrected by the artist in the drawing, with a view to ensuring that its gaze was pointing in the right direction. Infrared and X-ray imaging of the Peasant Wedding (cat. 80) revealed the original erotic and ironic character of the peasant portrayals. Beneath the overpainting, which was probably carried out in the seventeenth century, an amorous couple on top of the haystack appeared, while the codpiece of the bag- piper at the front became visible in their original size. The long-held belief that the painting was linked with The Wedding Dance (Detroit Institute of Art) has been disproved by provenance research and by the dendrochronological analysis conducted under the project.

The symposium held as part of the project served in the main as an opportunity to present more detailed the conclusions that are also found in the catalogue and essays. In addition to the lectures that have already been mentioned, other lectures gave detailed accounts of the technical observations and analysis conducted on the works in Vienna (Pascale Fraiture and Armelle Weitz: Dendrochronology of the Panels by Pieter Bruegel the Elder in the Collection of the Kunsthistorisches Museum Vienna; Ingrid Hopfner and Georg Prast: Bruegel's Panel Paintings in Vienna. Remarks on Their Construction and Condition; The Cleaning and Restoration of Bruegel's Panel Painting The Suicide of Saul). Still other lectures discussed, among other things, the connection between the Flemish master and the painting of miniatures, thereby convincingly demonstrating - based partly on previous research - similarities in terms of their motifs and their technical features (Till-Holger Borchert: Bruegel and the Tradition of Book Illumination). Other topics covered were the technical examinations conducted by other museums as well as the restoration of paintings and the consequences thereof (Maria Antonia López de Asián and Joés de la Funete Martinez: The Restoration of the Triumph of Death by Pieter Bruegel the Elder at the Prado Museum). Albeit not strictly related to a technological issue, one of the most exciting lectures concerned the Seasons cycle (Tine Luk Meganck: Between Brussels and Antwerp. New Perspectives on Bruegel's Cycle of the Seasons). A persuasive reconstruction of the arrangement of the series, which originally comprised six works, was made. It is known that Bruegel received a commission for the cycle from a close associate named Niclaes Jongelink, who wished to hang the paintings at his villa (Ter Beke villa). However, there are no surviving data concerning its original installation, and the building itself was subsequently destroyed. Meganck argues, with reference to the tapestries of the period, that the paintings were probably hung on the four walls of a dining room, with the two summer paintings and the two winter paintings being placed as pairs on opposing walls and the autumn and spring paintings on the perpendicular walls. The digital reconstruction seemed very credible; indeed, placing the two summer and two winter paintings in this arrangement seemed to be highly effective. Nevertheless, the exhibition curators 
emphasised that the summer and winter panels do not fit together as pairs, although they too suggested that the various seasons are likely to have been placed on different walls. Sadly, the exhibition did not include an interior where the entire known cycle - even if only in the form of prints - could have been presented as part of a similar installation. It would have been worth the experiment.

Evidently, the several examples that have been cited cannot convey the full splendour of the exhibition and the multifaceted nature of the findings. While the exhibition is now behind us, we still have access to the catalogue and the e-book, as well as to the excellent photographs on the website. Moreover, a symposium volume will be published in the next future. All this is no mean achievement. In the same vein, a further milestone in research would be - as the exhibition's curators have also indicated - the publication of a catalogue raisonné, including the results of technical investigations and their conclusions. There can be no doubt that such a catalogue would give further impulses to scholarly research on Bruegel's oeuvre, creating a new opus that would bring us even closer to this key figure in European art.

\section{NOTES}

${ }^{1}$ Televised interview with Charles de Tolnay, 1978. Cited in Tolnay, Károly: Teremtố géniuszok. Van Eycktôl Cézanne-ig [Creative geniuses. From Van Eyck to Cézanne], compiled and edited by Tímár, Árpád, Budapest, 1978 (the quoted passage is from the blurb on the dust jacket).

${ }^{2}$ On Charles de Tolnay's research on Netherlandish painting, see URBACH, Zsuzsa: Tolnay Károly múvészettörténeti munkássága. Németalföldi múvészet [The art historical work of Károly Tolnay. Netherlandish art], Ars Hungarica VII. 1979. 122-128; Ernô Marosi's epilogue, in TOLnAY 1978.

${ }^{3}$ http://www.getty.edu/foundation/initiatives/current/ panelpaintings/index.html.

${ }^{4}$ Popper, Leo: Pieter Brueghel der Ältere, Kunst und Künstler 8. 1910. 599-606. Popper's article is thoroughly analysed in Gosztonyi, Ferenc: The Early Reception of Cézanne in Hungary, 1906-10: Fülep and Popper, in Cézanne and the Past. Tradition and Creativity, edited by GESKó, Judit, exhibi- tion catalogue (Budapest, Szépmúvészeti Múzeum, 2012), Budapest, 2012. 179-190.

${ }^{5}$ Van Schoute, Roger and Verogstraete, Hélène: A Painted Wooden Roundle by Pieter Bruegel the Elder, The Burlington Magazine 142. 2000. 140-146. In his 2007 book on Bruegel, Manfred Sellink accepted the attribution, while also emphasising the lesser quality of some of the details in the painting. Cf. Sellink, Manfred: Bruegel. The Complete Paintings, Drawings and Prints, Gent, 2007. 112-113, cat. 62.

${ }^{6}$ Listed in SELLink 2007, cat. X1-X15.

${ }^{7}$ Gruber, Gerlinde: Das Bilderverzeichnis der Pressburger Burg von 1781. Ein Beitrag zur Sammlungsgeschichte der Gemäldegalerie des Kunsthistorischen Museums, Jahrbuch des Kunsthistorischen Museums Wien 8/9. 2006-2007. 354-400 / 363, note 61 (with references).

${ }_{9}^{9}$ Allart, Dominque and Currie, Christina: The Brueg(h)el Phenomenon, 3 volumes, Turnhout, 2012.

10 See Allart and Curie 2012. 